\title{
Web-Based Expert System for Diagnosis of Pigeon Disease by Naïve Bayes Method
}

\author{
Muhamad Yulianto Prastyo ${ }^{1}$, Ucuk Darusalam $^{2}$, Benrahman $^{3}$ \\ * Sistem Informasi, Universitas Nasional \\ **Falkutas Teknik Informasi dan Teknologi, Universitas Nasional \\ prastio391@gmail.com ${ }^{1}, \underline{\text { ucukdarusalam@gmail.com }}$, $\underline{\text { ben.rahman@gmail.com }}$ @
}

\begin{tabular}{l} 
Article Info \\
\hline Article history: \\
Received 2020-12-01 \\
Revised 2020-12-05 \\
Accepted 2020-12-09 \\
\hline
\end{tabular}

Keyword:

Expert System,

Naïve Bayes,

Web Based,

Pigeons

\begin{abstract}
Pigeons are very close to human life, therefore doves are often pets or livestock. Caring for pigeons because of their uniqueness and care is not that difficult. Many people do not know how to treat pigeons with the disease first. Therefore we need advice from experts on pigeons to treat the diseases. Because the disease in pigeons can attack humans, it must be treated first. To overcome this problem, an expert system was built which was equipped with 10 diseases and 33 symptoms obtained from an expert person. The Nä̈ve Bayes method is a simple classification method which results in a probability value for each diseases that appears. This system is made with the advantages of a user-friendly display on the symptoms selection page. The final result of the diagnosis is according to the first treatment method before being taken to the vet, using a web-based system which can make it easier for users to get information for disease diagnosis in pigeons. System accuracy testing conducted on 20 cases obtained a statistical probability of disease $90 \%$ of the system's success rate.
\end{abstract}

This is an open access article under the CC-BY-SA license.

\section{Pendahuluan}

Burung merpati termasuk dalam famili Columbide dari ordo Combuformes. Jenis burung kicau yang mencakup sekitar 300 Spesies burung [1]. Pada zaman dahulu burung merpati dilatih untuk menjadi merpati pos karena merpati mempuyai naluri alami yang dapat kembali ke sarangnya walaupun sudah pergi jauh. Pada masa perang merpati membantu untuk mengirim suratmenyurat [2]. Pada saat sekarang merpati sudah tidak hanya dijadikan sebagai merpati pos, melainkan menjadi merpati acuan, merpati hias, dan merpati dagingan kadang sebagai hewan peliharaan.

Burung merpati salah satu ungas yang sering menjadi hewan peliharaan/ternak, karena memiliki berbagai keunikan [1-2]. Selain postur tubuhnya yang manis dan menarik, merpati juga salah satu ungas yang jinak walaupun tidak mudah untuk memegangnya. Burung merpati mempunyai harga jual yang cukup tinggi, sehingga tidak heran memelihara burung merpati selain hobi juga sebagai mata pencaharian. Merawat burung merpati membutuhkan kasih sayang layaknya anak sendiri, merawat, menjaga, dan melihat perkembangannya merupakan hal yang sangat penting. Melihat tingkah lakunya akan memberikan kebahagiaan tersendiri bagi pemilik. Namun kebahagiaannya akan berkurang bila melihat hewan peliharaannya tersebut sakit atau mengalami gejala yang tidak biasa terjadi dalam kesehariaannya [3].

Sebagian peternak dan penghobi hanya dapat memelihara burung merpati tanpa mengerti apa yang harus dilakukan jika timbul gejala-gejala penyakit tertentu [4]. Oleh karna itu kesehatan hewan ternak harus selalu diperhatikan. Burung merpati merupakan salah satu ungas yang rawan terhadap penyakit. Penyakit ungas tidak hanya sekedar meyerang sesama ungas tetapi juga menyerang manusia. Salah satu penyakit yang meyerang manusia adalah flu burung. Sementara itu proses diagnosa suatu penyakit hewan ternak seperti burung merpati tersebut hanya dapat dilakukan oleh pakar penyakit hewan atau dokter hewan. Selain itu sebagai alternative lain dapat melakukan dianogsa menggunakan sistem pakar [5] dengan memberikan algoritma tertentu dalam memecahkan penyelesaiannya. Pada penelitian kali ini, menerapkan algoritma naïve bayes dalam bentuk website. Metode naïve bayes, berguna untuk pengklasifikasi beberapa kondisi atribut dari suatu kasus gejala yang diderita untuk menghasilkan kategori yang menjadi probabilitas tertinggi [6].

Telah banyak penelitian tentang sistem pakar, maka dari itu penelitian kali ini mengacu pada beberapa jurnal diantaranya 
adalah penelitian tetang penyakit pada ungas atau burung. Penelitian sebelumnya yang dilakukan di Bangladesh selama satu tahun mendapatkan 14 penyakit dari 502 burung merpati, yang di akibatkan oleh parasit, bakteri, virus, jamur dan lainya [7]. Penyakit yang diakibatkan oleh virus salah satunya Newcastle disease atau bisa disebut juga dengan Tatelo ya di sebabkan oleh virus Paramyxovirus serotype 1 (APMV1) yang menginfeksi saluran pernapasan pada burung [8].

Pada penelitian selanjutnya mendiagnosa penyakit ayam dengan metode naïve bayes dan certainty faktor dengan aplikasi berbasis android dengan nilai keakurasian dari dua metode yang digunakan adalah 90\% [9]. Penelitian lain tentang identifikasi penyakit burung puyuh dengan metode Inferensi Forward Chaining dengan aplikasi berbasis android, membutuhkan nilai bobot atau nilai probabilitas yang lebih valid untuk hasil keakurasian yang sempurna [10]. Pada penelitian lain lagi tentang burung lovebird dengan metode forward chaining berbasis android untuk membantu perternak dan penghobi awam tetang burung lovebird dengan fakta-fakta atau gejala-gejala yang dialami oleh lovebird, selanjutnya sistem akan memberikan saran solusi, berupa hasil diagnosanya [11].

Tujuan penelitian ini bagaimana membangun sebuah aplikasi berbasis website untuk mendiagnosa penyakit pada burung merpati yang dilengkapi dengan pemberian saran terhadap penyakit yang terdiagnosa hasil pengisian beberapa pertanyaan. Selain itu untuk mengetahui probabilitas statistik penyakit pada burung merpati dengan penerapan Naïve Bayes.

\section{Metode Penelitian}

Penelitian ini mengunakan metode Naïve Bayes. Implementasi sistem dalam bentuk aplikasi berbasis web. Naïve Bayes sendiri merupakan salah satu metode yang menggunakan perhitungan probabilitas dan statistik. Keuntungan klasifikasi Naïve Bayes adalah metode ini hanya membutuhkan jumlah data pelatihan yang kecil untuk menentukan estimasi parameter yang diperlukan dalam proses pengklasifikasian.

Langkah-langkah perhitungan dengan metode Nä̈ve Bayes sebagai berikut [7].

1. Menentukan kategori (penyakit) yang muncul berdasarkan data latih.

2. Menghitung nilai probabilitas penyakit dan gejala.

3. Menghitung nilai bayes berdasarkan probabilitas penyakit dan gejala yang timbul.

Dalam proses rumus probabilitas naïve bayes sebagai berikut.

Dimana:

$$
P(H \mid X)=\frac{P(X \mid H) P(H)}{P(X)}
$$

$\mathrm{X}=$ merupakan data class yang belum diketahui

$\mathrm{H}=$ hipotesis data merupakan suatu class yang spesifik

$\mathrm{P}(\mathrm{H} \mid \mathrm{X})=$ merupakan probabilitas hipotesis $\mathrm{H}$ berdasarkan kondisi X (posterior probabilitas)
$\mathrm{P}(\mathrm{H})=$ probabilitas hipotesis $\mathrm{H}$ (prior probabilitas)

$\mathrm{P}(\mathrm{X} \mid \mathrm{H})=$ probabilitas $\mathrm{X}$ berdasarkan kondisi $\mathrm{H}$

$\mathrm{P}(\mathrm{X})=$ probabilitas dari $\mathrm{X}$

Metode penelitian dijelaskan pada desain penelitian, gambar 1 sebagai berikut.

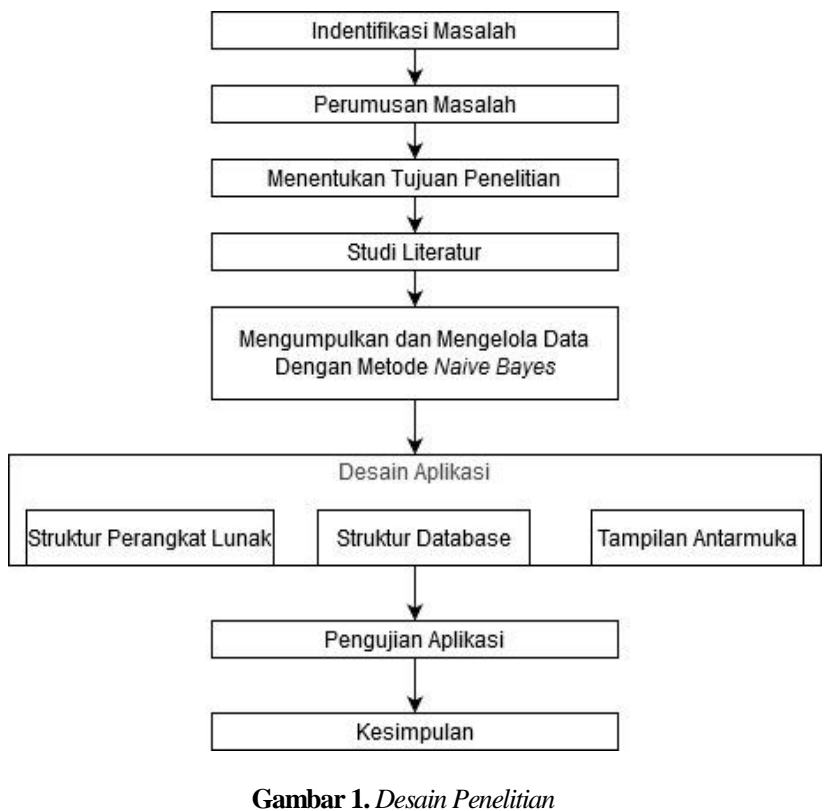

Gambar 1 menjelaskan desain penelitian dimana tahapantahapan penelitian yang akan dilakukan dimulai dari identifikasi masalah, perumusan masalah, menentukan tujuan penelitian, mengumpulkan data dan mengelola dengan metode Nä̈ve Bayes, Desain Aplikasi, Pengujian Aplikasi dan menentukan kesimpulan . Berdasarkan hasil wawancara dengan pakar di dapatkan beberapa data gejala dan penyakit yang di alami burung merpati di jelasakan pada tabel 1 sebagai berikut.

TABEL 1

KODE DAN DATA PENYAKIT

\begin{tabular}{|c|c|}
\hline Kode & Nama Penyakit \\
\hline P01 & Tatelo \\
\hline P02 & Pigeon Pox \\
\hline P03 & Berak Kapur \\
\hline P04 & Snot/Coryza \\
\hline P05 & Paratyphoid \\
\hline P06 & Bubul \\
\hline P07 & Cacingan \\
\hline P08 & Diare Burung \\
\hline P09 & Kutu Burung \\
\hline P10 & Canker/Goham \\
\hline
\end{tabular}

Pada tabel di atas terdapat 10 data penyakit pada burung merpati yang di berikode $\mathrm{P}$ untuk peyakit. Untuk mendiagnosa membutuh gejala pada tabel 2 menjelaskan gejala sebagai berikut. 
TABEL II

Kode Dan Data GeJala

\begin{tabular}{|c|l|}
\hline Kode & \multicolumn{1}{|c|}{ Gejala } \\
\hline G1 & Sering Bersin-bersin \\
\hline G2 & Pernapasan sesak \\
\hline G3 & Hidung lembab/Berlendir \\
\hline G4 & Sayap terlihat lemas \\
\hline G5 & Kulit Melepuh seperti terbakar \\
\hline G6 & Kulit Bintik-bintik \\
\hline G7 & Muncul benjolan pada kulit \\
\hline G8 & Kotoran burung berwana putih \\
\hline G9 & Nafsu Makan berkurang \\
\hline G10 & kesulitan membuang kotoran \\
\hline & Banyak Kotoran Yang berwan putih nembel pada \\
\hline G11 & Bulu disekitaran anus \\
\hline G12 & Bulu tidak teratur \\
\hline G13 & Sayap Menggantung \\
\hline G14 & Burung kurang bergairah \\
\hline G15 & Muka Bengkak \\
\hline G16 & Tidak Mau makan \\
\hline G17 & Mengluarkan kotoran berwana hijau di sertai busa \\
\hline G18 & Bulu leher berdiri \\
\hline G19 & Muncul bengkak Pada Persendian \\
\hline G20 & Leher tidak bisa Berdiri \\
\hline G21 & Kaki membengkak \\
\hline G22 & kaki merengang \\
\hline G23 & Berat badan Burung menurun \\
\hline G24 & Kotoran cair disertai putih-putih berkerak \\
\hline G25 & Kotoran cair berwana keruh disertai bau busuk \\
\hline G26 & Gelisah \\
\hline G27 & sering mengigiti bulu \\
\hline G28 & Tidak tidur pada malah hari \\
\hline G29 & Terdapat benjolan Kuning di area rongga mulut \\
\hline G30 & Nafsu minum lebih tinggi dari pada makan \\
\hline G31 & Mata lambat dalam berkedip \\
\hline G32 & Bulu terlihat kasar dan kusam \\
\hline G33 & Kotoran Berbentuk cair \\
\hline & \\
\hline
\end{tabular}

Pada tabel 2 merupakan tabel gejala yang didapatkan dari pakar dengan kode G. Setelah mendapat data penyakit dan gejala untuk menajalan programnya dibutuhkan aturan untuk mendiagnosa penyakit pada burung merpati.

TABEL III

Kode Penyakit dan Aturan

\begin{tabular}{|c|c|}
\hline Kode Penyakit & Kode Aturan \\
\hline P01 & G1,G2,G3,G4 \\
\hline P02 & G5,G6,G7 \\
\hline P03 & G8,G9,G10,G11,G12,G13,G14 \\
\hline P04 & G1,G2,G3,G9,G15 \\
\hline P05 & G21,G22 \\
\hline P06 & G9,G12,G14,G23,G24 \\
\hline P07 & G23,G25 \\
\hline P08 & G26,G27,G28 \\
\hline P09 & G29,G30,G31,G32,G33 \\
\hline P10
\end{tabular}

Tabel 3 merupakan aturan untuk sistem memaksimalkan kinerja. Diagnosa membutuhkan nilai probalitas penyakit yang dihitung dari data latih. Pada gambar 2 merupakan flowchart metode untuk mendapat nilai probalitas.

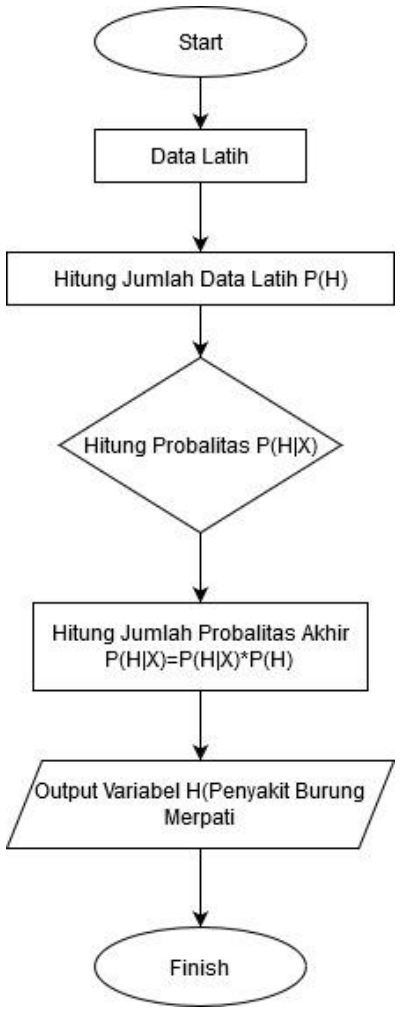

Gambar 2. Flowchart Metode

Pada gambar 2 menjelaskan tahapan-tahapan untuk mendapat nilai probalitas yang akan dimulai dengan membuat data latih, hitung jumlah data latih, hitung probalitas, hitung probalitas akhir dengan metode Naïve Bayes dan outputnya untuk mengetahui penyakit yang di derita oleh burung merpati.

\section{HASIL DAN PEMbahasan}

Untuk mendapatkan nilai probalitas maka perlu melakukan simulasi perhitungan manual dari setiap penyakit dan gejala. Pada tabel di bawah merupakan contoh untuk mendapatkan nilai probalitas.

TABEL IV

CONTOH KASUS PENYAKIT

\begin{tabular}{|c|c|c|c|}
\hline Gejala & Pilihan & Gejala & Pilihan \\
\hline G01 & Ya & G18 & Tidak \\
\hline G02 & Ya & G19 & Tidak \\
\hline G03 & Ya & G20 & Tidak \\
\hline G04 & Tidak & G21 & Tidak \\
\hline G05 & Tidak & G22 & Tidak \\
\hline G06 & Tidak & G23 & Tidak \\
\hline G07 & Tidak & G24 & Tidak \\
\hline
\end{tabular}




\begin{tabular}{|c|c|c|c|}
\hline G08 & Tidak & G25 & Tidak \\
\hline G09 & Ya & G26 & Tidak \\
\hline G10 & Tidak & G27 & Tidak \\
\hline G11 & Tidak & G28 & Tidak \\
\hline G12 & Tidak & G29 & Tidak \\
\hline G13 & Tidak & G30 & Tidak \\
\hline G14 & Tidak & G31 & Tidak \\
\hline G15 & Ya & G32 & Tidak \\
\hline G16 & Tidak & G33 & Tidak \\
\hline G17 & Tidak & \multicolumn{2}{|l}{} \\
\cline { 1 - 2 }
\end{tabular}

Tabel 4 merupakan contoh untuk mendapat nilai probalitas per gejala dengan kemunkinan Ya dan Tidak. Tabel selanjutnya untuk mengetahui nilai probalitas penyakit.

TABEL V

Menghitung Nilai Probalitas PenyaKit

\begin{tabular}{|lc|c|}
\hline \multicolumn{2}{|c|}{ Jumlah class (X=Penyakit) } \\
\hline $\mathrm{P}(\mathrm{X}=$ Tatelo $)$ & $6 / 60$ & 0.1 \\
\hline $\mathrm{P}(\mathrm{X}=$ Pigeon Pox $)$ & $5 / 60$ & 0.083 \\
\hline $\mathrm{P}(\mathrm{X}=$ Berak Kapur $)$ & $5 / 60$ & 0.083 \\
\hline $\mathrm{P}(\mathrm{X}=$ Snot/Coryza $)$ & $7 / 60$ & 0.116 \\
\hline $\mathrm{P}(\mathrm{X}=$ Paratyphoid $)$ & $6 / 60$ & 0.1 \\
\hline $\mathrm{P}(\mathrm{X}=$ Bubul $)$ & $5 / 57$ & 0.083 \\
\hline $\mathrm{P}(\mathrm{X}=$ Cacingan $)$ & $7 / 60$ & 0.116 \\
\hline $\mathrm{P}(\mathrm{X}=$ Diare Burung $)$ & $7 / 60$ & 0.116 \\
\hline $\mathrm{P}(\mathrm{X}=$ Kutu Burung $)$ & $5 / 60$ & 0.083 \\
\hline $\mathrm{P}(\mathrm{X}=$ Canker/Goham $)$ & $7 / 60$ & 0.116 \\
\hline
\end{tabular}

Tabel 4 merupakan nilai probalitas perpenyakit dengan data latih yang berjumlah 60. Untuk mendapatkan nilai probalitas per-gejala dengan memasukan kemukinan Ya dan Tidak pada tabel 5 sebagai berikut.

TABEL VI

Perhitungan Nilai Probalitas Gejala

\begin{tabular}{|l|l|l|l|l|l|}
\hline & G01-Ya & G02-Ya & G03-Ya & $\begin{array}{l}\text { G04- } \\
\text { Tidak }\end{array}$ & $\begin{array}{l}\text { G05- } \\
\text { Tidak }\end{array}$ \\
\hline P01 & 0.833 & 0.833 & 0.5 & 0.333 & 0.833 \\
\hline P02 & 0.2 & 0.2 & 0.2 & 0.8 & 0.2 \\
\hline P03 & 0.2 & 0.2 & 0.2 & 0.8 & 0.8 \\
\hline P04 & 0.714 & 0.714 & 0.857 & 0.857 & 0.857 \\
\hline P05 & 0.166 & 0.166 & 0.166 & 0.833 & 0.833 \\
\hline P06 & 0.2 & 0.2 & 0.2 & 0.8 & 0.8 \\
\hline P07 & 0.142 & 0.142 & 0.142 & 0.857 & 0.857 \\
\hline P08 & 0.142 & 0.142 & 0.142 & 0.857 & 0.857 \\
\hline P09 & 0.2 & 0.2 & 0.2 & 0.8 & 0.8 \\
\hline P10 & 0.142 & 0.142 & 0.142 & 0.714 & 0.857 \\
\hline
\end{tabular}

Pada tabel 6 merupakan perhitungan per-gejala dari 33 gejala dimasukan hanya 5, nilai probalitas per-gejala akan menjadi acuan sistem untuk menghasilkan diagnosa.
TABEL VII

HASIL PROBABILITAS

\begin{tabular}{|l|c|}
\hline \multicolumn{1}{|c|}{ Penyakit } & Nilai Probalitas \\
\hline Tatelo & 0.000001404200000 \\
\hline Pigeon Pox & 0.000000001007438 \\
\hline Berak Kapur & 0.000000000251859 \\
\hline Snot/Coryza & 0.000600511717180 \\
\hline Paratyphoid & 0.000000000049928 \\
\hline Bubul & 0.000000003223802 \\
\hline Cacingan & 0.000000000286023 \\
\hline Diare Burung & 0.000000000429035 \\
\hline Kutu Burung & 0.000000000604462 \\
\hline Caker/Goham & 0.000000000119176 \\
\hline
\end{tabular}

Pada tabel 7 merupakan hasil dari perkalian dari setiap gejala dengan jumlah perpeyakit. Hasil tersebut diperoleh kesimpulan dari contoh kasus yang di uji, nilai probilitas tertinggi adalah Snot /Coryza dengan nilai probilitas 0.000600511717180. Maka dapat disimpulkan bahwa penyakit yang diderita oleh burung merpati pada perhitungan simulasi ini adalah Snot /Coryza.

\section{A. FLOWCHART SISTEM}

Flowchart sistem bertujuan untuk menjelaskan alur sistem pada sistem pakar diagnosa penyakit yang dibuat pada aplikasi berbasis web oleh pengguna akhir (end user).

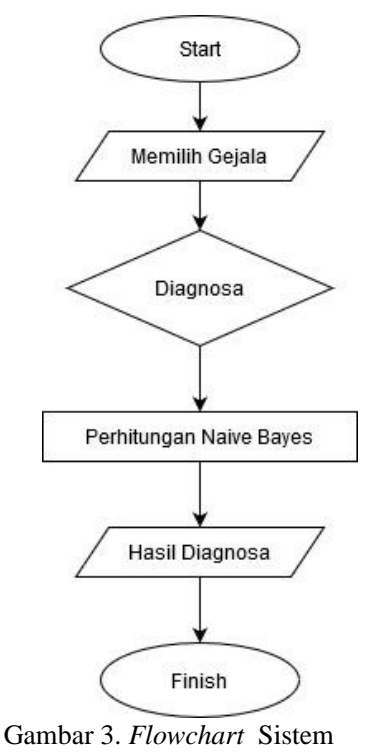

Pada gambar 3, menunjukkan bahwa pengguna (end user) dapat langsung memilih gejala-gejala yang ada pada setiap peyakit burung merpati. Jika diagnosa penyakit ditemukan, selanjutnya sistem melakukan penghitungan sesuai simulasi yang telah dijelaskan sebelumnya menggunakan Naïve Bayes. Sistem akan menampilkan hasil diagnosa dari gejala yang dipilih dan penyakit pada burung merpati. 


\section{B. PERACANGAN USECASE DIAGRAM}

Perancangan aktifitas sistem yang dibuat berdasarkan fungsional dari masing-masing kebutuhan.

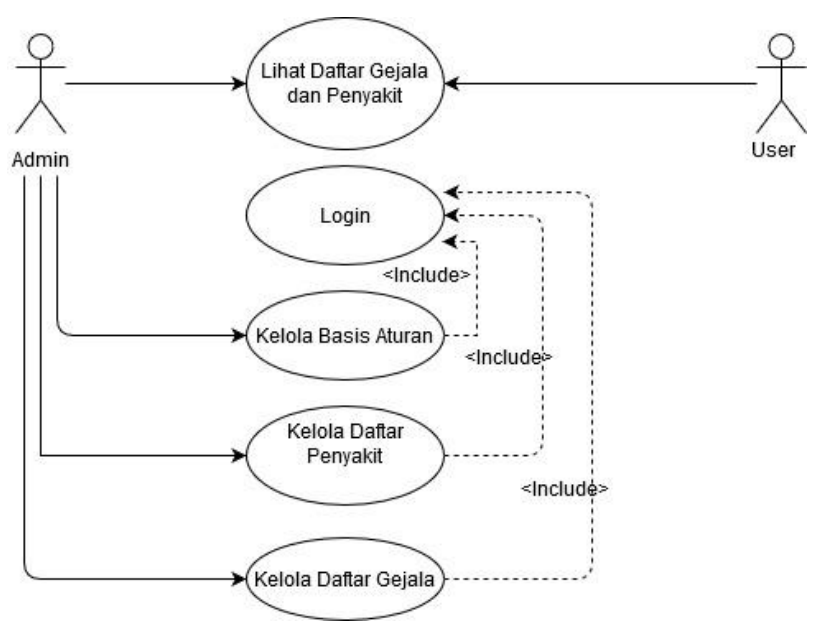

Gambar 4. Use Case Diagram Sistem

Aktor yang terlibat dalam aplikasi diagnosa berbasis web terdiri dari pengguna (end user) dan admin. End user merupakan pengguna yang dapat melakukan konsultasi atas gejala yang diderita burung merpati. Aktor ini cukup menjawab beberapa pertanyaan dari sistem, untuk memperoleh hasil analisa diagnosis penyakit yang dialami. Admin memiliki hak akses penuh terhadap sistem. Aktor ini diperlukan dalam melakukan update data gejala dan penyakit burung merpati serta aturan dalam Naive Bayes.

\section{HASIL EKSEKUSI PROGRAM}

Hasil akhir penelitian ini adalah sistem pakar mendiagnosa penyakit pada burung merpati berbasis web dengan metode naive bayes. Hasil eksekusi merupakan menu utama, halaman gejala, dan hasil diagnosa penyakit. Menu utama merupakan halaman utama saat menajalkan sistem pertama kali.

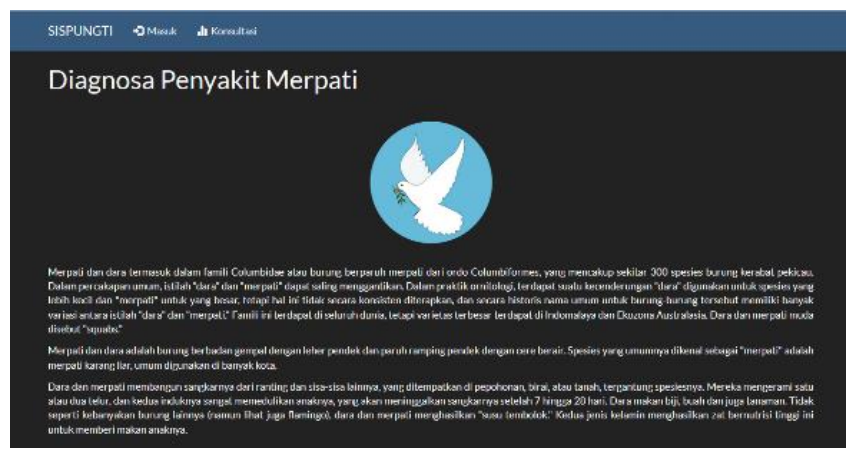

Gambar 3. Menu utama
Setelah memasuki menu utama yang menjelaskan tetang burung merpati. User dapat memasuki menu konsultasi seperti gamabr di bawah ini.

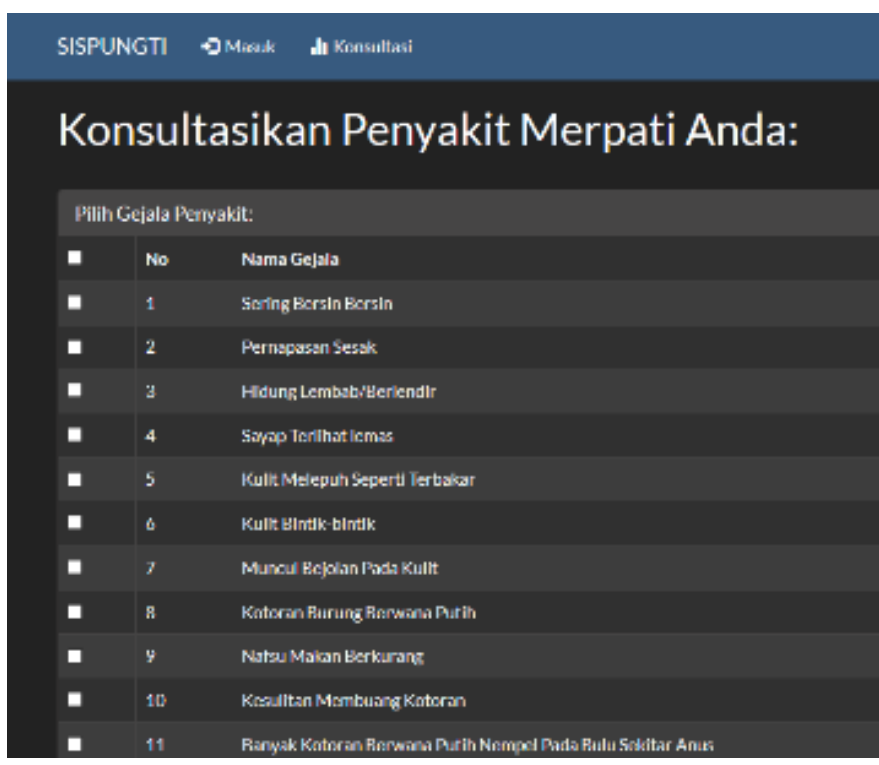

Gambar 4. Halaman Konsultasi

Halaman konsultasi merupakan halaman dimana user mengisi gejala penyakit yang di derita pada burung merpatinya. Berdasarkan gejala yang di pilih user akan menghasilkan diagnosis penyakit yang diderita burung merpati, berikut hasil diagnosa.

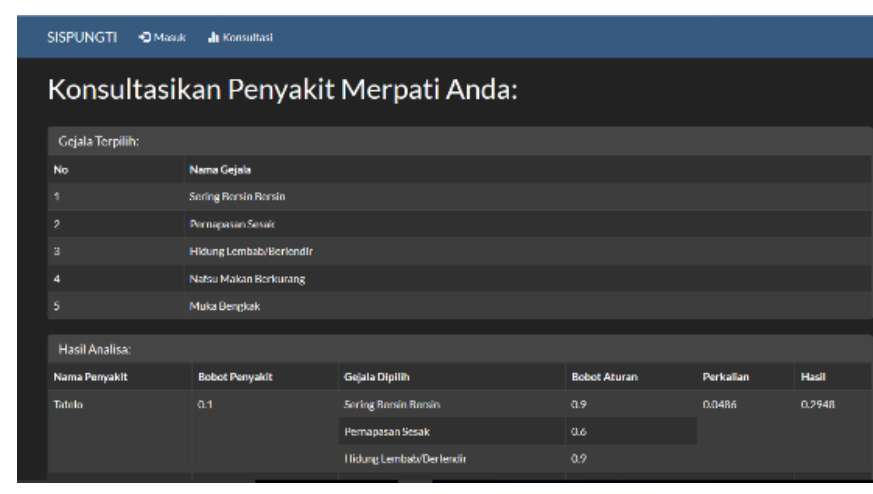

Gambar 5. Halaman Hasil Diagnosa

Halaman hasil diagnosa merupakan hasil akhir dari pengisian gejala dan hitung dengan metode Naive Bayes yang nilai probalitas tinggi maka itulah penyakit yang diderita oleh burung merpati user. 


\section{UJI KEAKURATAN PROGRAM}

Uji keakuratan dilakukan dengan percobaan 20 data gejala hanya 7 kasus yang sesuai sebagai berikut.

TABEL 8

PENGUJian Sistem DENGAN PAKAR

\begin{tabular}{|l|l|l|l|c|}
\hline No & \multicolumn{1}{|c|}{ Gejala } & \multicolumn{1}{|c|}{ Sistem } & \multicolumn{1}{|c|}{ Pakar } & Hasil \\
\hline 1 & $\begin{array}{l}\text { G01,G02, } \\
\text { G03 }\end{array}$ & Tatelo & Tatelo & S \\
\hline 2 & $\begin{array}{l}\text { G01,G02, } \\
\text { G04,G09 }\end{array}$ & Snot & Snot & S \\
\hline 3 & $\begin{array}{l}\text { G03,G09, } \\
\text { G15 }\end{array}$ & Snot/Coryza & Snot & S \\
\hline 4 & $\begin{array}{l}\text { G08,G09, } \\
\text { G12,G24 }\end{array}$ & Cacingan & Cacingan & S \\
\hline 5 & $\begin{array}{l}\text { G05,G06, } \\
\text { G12,G18 }\end{array}$ & Pigeon Pox & Pigeon Pox & S \\
\hline 6 & G16,G17, & Paratyphoid & Paratyphoid & S \\
\hline 7 & G1 & Snot/Coryza & Tidak ada penyakit & TS \\
\hline
\end{tabular}

Keterangan:

$\mathrm{S}$ = Sesuai

TS = Tidak Sesuai

Berdasarkan hasil pengujian akurasi sistem maka di dapatkan probabilitas statistik [4-6][13-14]:

$$
\begin{gathered}
\frac{\text { Banyak Data Sesuai }(\text { Benar })}{\text { Banyak Data Kasus }} \times 100 \% \\
=\frac{18}{20} \times 100 \%=90 \%
\end{gathered}
$$

Dari 20 data kasus terdapat 18 data yang sesuai atau benar dari pengujian sistem web dan pakar. Berdasarkan hasil perhitungan persentase tersebut akurasi sistem bahwa aplikasi sistem pakar untuk diagnosa penyakit burung merpati dengan metode naive bayes memiliki tingkat probabilitas statistik penyakit sebesar $90 \%$ akurasi atau keberhasilan.

\section{KESIMPULAN}

Hasil penelitian dan pembahasan yang telah dilakukan, terkait pembuatan sistem pakar untuk diagnosa penyakit burung merpati mengunakan metode Naïve Bayes, dapat ditarik kesimpulan bahwa sistem dapat memberikan informasi berupa diagnosa penyakit burung merpati berdasarkan penerapan metode naïve bayes disertai dengan solusi pengobatan. Adanya sistem pakar yang telah di buat maka akan mempermudah perternak atau penghobi burung merpati dalam mendiagnosa awal penyakit burung merpatinya sehingga bisa dilakukan pengobatan awal. Selain itu adanya website ini juga, user dapat dengan mudah berkonsultasi tanpa harus mendaftar. Pengujian akurasi sistem yang dilakukan terhadap 20 kasus mendapatkan probabilitas statistik penyakit $90 \%$ tingkat keberhasilan sistem.

\section{DAFTAR PUSTAKA}

[1] Ismadi, "Panduan Sukses Budidaya Burung Merpati, Jawa Tengah; Desa Pusaka Indonesia", Penerbit Indoliterasi, 2019.

[2] S. Neni, "Petunjuk Praktis Berternak Merpati", Bandung: Nuasa Cenkidia, 2007.

[3] D. A. Dwi, "Penerapan Forward Chaining Untuk Diagnosa Penyakit Pada Burung Merpati Berbasis Web," Amikom Yogyakarya, July 2015.

[4] T. Tristono, A. Budiman, and B. A. Permana, "Sistem Pakar Berbasis Web Untuk Diagnosa Penyakit Burung Merpati," Unmermadiun.ac.id. [Online]. Available: http://www.unmermadiun.ac.id/repository_jurnal_penelitian/Jurnal\% 20Agritek/Jurnal\%20Agri-tek\%202012/September/6_TomiTristiono\%20hal\%2053-59.pdf. [Accessed: 08-Dec-2020].

[5] D. P. Widjanarko, "Sistem Pakar Deteksi Dini Penyakit Pada Burung Puyuh Dengan Metode Forward Chaining," Dinus.ac.id. [Online]. Available: http://eprints.dinus.ac.id/16976/1/jurnal_16198.pdf. [Accessed: 08-Dec-2020].

[6] F. Fadhilah, "Penerapan Metode Naive Bayes Pada Aplikasi Sistem Pakar Untuk Diagnosa Penyakit Kulit Pada Kucing,” J. infomedia, vol. 5, no. 1, pp. 23-30, 2020.

[7] T.K.Paul, "Occurrence of Pigeon Diseases at Khulna Sadar, Bangladesh," Bangl. J. Vet. Med, 13(2):21-25, Des 2015

[8] G. Mebrate," Epidemiology, Diagnosis \& Prevention of Newcastle Disease in Poultry,"American Journal of Biomedical Science \& Research, 51(5): 1033-1048, Mar 2019.

[9] Y. E. Windarto and M. Marfuah, "Implementasi Naives BayesCertainty Factor untuk Diagnosa Penyakit Menular," Jurnal Sisfokom (Sistem Informasi dan Komputer), vol. 9, no. 2, p. 208, 2020.

[10] M. H. Sukmawan, "Sistem Pakar Identifikasi Penyakit Burung Puyuh Menggunakan Metode Inferensi Forward Chaining Berbasis Android," J-INTECH, vol. 6, no. 01, pp. 63-77, 2018.

[11] D. S. J. Rahardjo," Diagnosis Penyakit Pada Burung Lovebird Dengan Algoritma Forward Chaining,"AJCSR,Vol 2, No 2, July 2020

[12] Y. Eric,"Penyakit dan Penanggulangannya" Melatih dan Merawat Burung Merpati Balap, Jakarta: PT.ArgoMedia Pustaka, 2003, 68-73

[13] A. A. S. Nugraha, N. Hidayat, and L. Fanani, "Sistem Pakar Diagnosis Penyakit Kucing Menggunakan Metode Naive Bayes Certainty Factor Berbasis Android," Ub.ac.id. [Online]. Available: http://j-ptiik.ub.ac.id/index.php/j-ptiik/article/download/903/351. [Accessed: 08-Dec-2020].

[14] M. D. Nurmalasari1) and A. D. Laksito, "Aplikasi Sistem Pakar Diagnosa Awal Penyakit Kucing Berbasis Android Dengan Metode Forward Chaining," Amikom.ac.id. [Online]. Available: https://ojs.amikom.ac.id/index.php/INFOSJournal/article/view/2332/ 2138. [Accessed: 08-Dec-2020]. 